\title{
Facile Synthesis and Cytotoxic Activity of the First Ferrocene-Resveratrol Conjugate
}

\author{
Veronika Kovač, Ivana Kmetič, Teuta Murati, Marina Miletić, Lidija Barišić*
}

\footnotetext{
${ }_{1}$ Department of Chemistry and Biochemistry, Faculty of Food Technology and Biotechnology, University of Zagreb, Pierottijeva 6, HR-10000 Zagreb, Croatia

* Corresponding author's e-mail address: lidija.barisic@pbf.hr
}

RECEIVED: September 7, 2016 * REVISED: October 26, 2016 * ACCEPTED: October 29, 2016

\begin{abstract}
The bioorganometallic III containing trimethylene chain between ferrocene and resveratrol (3,5,4'-trihydroxystilbene, RSV) moieties connected via ester bond has been synthesized. The novel bioconjugate was characterized using IR and NMR $\left({ }^{1} \mathrm{H},{ }^{13} \mathrm{C}, \mathrm{COSY}, \mathrm{NOESY}, \mathrm{HMBC}\right)$ spectroscopy, ESI-MS and HRMS. The RSV and ferrocene-RSV conjugate III were screened in vitro for their inhibitory effects against proliferation of hepatoblastoma (Hep G2) cells by MTT assay. Also, possible cytotoxicity towards normal ovary cells (CHO-K1) was evaluated. The obtained data revealed profound effects in biological/cytotoxic activity of III vs. RSV in Hep G2 cell line. Lower cytotoxicity of III was observed in normal ovary cells as compared to hepatoblastoma cells.
\end{abstract}

Keywords: ferrocene, ferrocene-resveratrol conjugate, hepatoblastoma, normal ovary cells, resveratrol.

\section{INTRODUCTION}

O WING to its therapeutic and protective role, resveratrol [3,5,4'-trihydroxystilbene (RSV) (Figure 1a)] came into focus of research in recent years. Among numerous health benefits, RSV improves cardioprotection, cancer prevention and therapy, immune regulation and<smiles>Oc1ccc(C=Cc2cc(O)cc(O)c2)cc1</smiles>

(b)

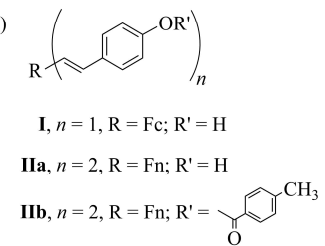

Figure 1. The chemical structures of (a) resveratrol (RSV), (b) ferrocene-RSV analogs $\mathbf{I}$ and $\mathbf{I I}$ and (c) ferrocene-RSV conjugate III. The numbering of the carbon atoms is according to IUPAC nomenclature. metabolic and neuroprotective functions. ${ }^{[1-3]}$ In order to enhance its activity, RSV was derivatized by: (i) modification of the number and position of the phenolic groups, (ii) insertion of a long alkyl chains or functionalized chains ${ }^{[4]}$ and (iii) the addition of acyl chains to free hydroxyl groups. ${ }^{[5]}$ The improved biological activity of the so-obtained RSV derivatives in comparison to those of the parent molecule is likely to be due to their lipophilicity and facilitated transport through cell membrane. Recently, RSV-derivatives I and II containing lipophilic ferrocene moiety instead of one benzene ring were synthesized (Figure 1b). ${ }^{[4]}$ The heteroannularly disubstituted derivative Ilb, containing additional aromatic unit linked by an ester bond, was found to exhibit more than 10-fold higher inhibitory activity in SW480 and HepG2 cell lines compared to those of RSV. Prompted by these results, we have prepared and tested conjugate III containing trimethylene alkyl chain between ferrocene and RSV connected via ester linkage (Figure 1c).

\section{EXPERIMENTAL}

The material and methods data are provided in Supplementary Materials. 


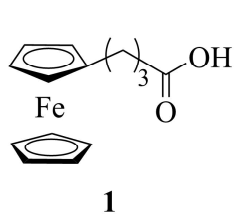<smiles>Oc1ccc(C=Cc2cc(O)cc(O)c2)cc1</smiles>

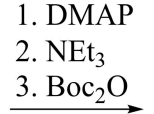

3. $\mathrm{Boc}_{2} \mathrm{O}$

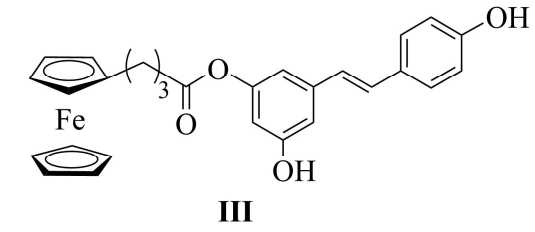

Scheme 1. The synthesis of ferrocene-RSV conjugate III.

\section{Chemistry}

The trans-resveratrol (RSV) (95 mg, $0.42 \mathrm{mmol}$ ) was dissolved in dry THF $(7 \mathrm{ml})$ and added to a solution of ferrocene butyric acid $\mathbf{1}^{[6]}$ ( $374 \mathrm{mg}, 1.37 \mathrm{mmol}$ ) in the same solvent $(10 \mathrm{ml})$, followed with addition of DMAP $(7.6 \mathrm{mg}$, $0.06 \mathrm{mmol})$ and $\mathrm{NEt}_{3}(0.35 \mathrm{ml}, 2.49 \mathrm{mmol})^{[7]}$ (Scheme 1). The reaction mixture was cooled to $-15^{\circ} \mathrm{C}$ and solution of $\mathrm{Boc}_{2} \mathrm{O}(354 \mathrm{mg}, 1.62 \mathrm{mmol})$ in dry THF $(8 \mathrm{ml})$ was added. After 5 minutes, the reaction mixture was allowed to warm to room temperature and then stirred at ambient temperature during 5 days. After the total consumption of the starting material, as monitored by TLC, the mixture was diluted with $\mathrm{EtOAc}(10 \mathrm{ml})$ and washed with $2 \mathrm{M} \mathrm{HCl}(30 \mathrm{ml})$, $5 \% \mathrm{NaHCO}_{3}(50 \mathrm{ml})$ and saturated $\mathrm{NaCl}$. The organic layer was dried over $\mathrm{Na}_{2} \mathrm{SO}_{4}$ and evaporated in vacuo to leave the crude product. Since the numerous yellow and UV visible spots were seen on TLC plate, the TLC purification of the crude material was repeated for several times using different solvent systems (petroleum ether/ diethyl ether = $2 / 1$; petroleum ether/diethyl ether $=5 / 1 ; \mathrm{CH}_{2} \mathrm{Cl}_{2} /$ hexane $=3 / 1$ ) until satisfactory purity of the compound III was obtained and confirmed by ESI-LC method. Yellow-orange oil; $43 \mathrm{mg}$ (21\%); $R_{\mathrm{f}}=0.68$ in petroleum ether/ diethyl ether $=2 / 1 ; \mathrm{IR}\left(\mathrm{CH}_{2} \mathrm{Cl}_{2}\right) \tilde{v}_{\max } / \mathrm{cm}^{-1}: 3676 \mathrm{w}(\mathrm{OH}), 1759 \mathrm{~s}(\mathrm{C}=0)$, $1137 \mathrm{~s}(\mathrm{CO}) ;{ }^{1} \mathrm{H}$ NMR $\left(\mathrm{CDCl}_{3}\right) \delta / \mathrm{ppm}: 1.54$ (brs, $\left.2 \mathrm{H}, \mathrm{OH}\right), 1.96$ $\left(\mathrm{m}, 2 \mathrm{H}, \mathrm{CH}_{2 \gamma}\right), 2.48\left(\mathrm{t}, J=2.5 \mathrm{~Hz}, 2 \mathrm{H}, \mathrm{CH}_{2 \delta}\right), 2.58(\mathrm{t}, J=2.6$ $\left.\mathrm{Hz}, 2 \mathrm{H}, \mathrm{CH}_{2 \beta}\right), 4.08\left(\mathrm{~s}, 2 \mathrm{H}, \mathrm{H}_{\mathrm{Fn}}\right), 4.11\left(\mathrm{~s}, 2 \mathrm{H}, \mathrm{H}_{\mathrm{Fn}}\right), 4.12(\mathrm{~s}, 5 \mathrm{H}$, $\left.\mathrm{H}_{\mathrm{Fn}}\right), 6.90(\mathrm{pt}, 1 \mathrm{H}, \mathrm{H} 4), 6.97(\mathrm{~d}, J=16.3 \mathrm{~Hz}, 1 \mathrm{H}, \mathrm{H \alpha}), 7.06$ (d, $\left.J=16.3 \mathrm{~Hz}, 1 \mathrm{H}, \mathrm{H} \alpha^{\prime}\right), 7.11$ (brs, $1 \mathrm{H}, \mathrm{H} 2$ ), 7.17 (d, $J=8.5 \mathrm{~Hz}$, $2 \mathrm{H}, \mathrm{H}^{\prime}, \mathrm{H} 5^{\prime}$ ), 7.19 (brs, $1 \mathrm{H}, \mathrm{H2}$ ), 7.47 (d, J=8.5 Hz, 2H, H2', $\left.\mathrm{H}^{\prime}\right) ;{ }^{13} \mathrm{C}$ NMR APT $\left(\mathrm{CDCl}_{3}\right) \delta / \mathrm{ppm}: 171.70(\mathrm{C}=\mathrm{O}), 151.89$ (C3), 151.88 (C5), 151.47 (C4'), 139.63 (C1), 134.53 (C1'), $129.78\left(\mathrm{C} \alpha^{\prime}\right), 172.75$ (C2', C6'), 129.38 (Ca), 121.74 (C3', $\left.\mathrm{C}^{\prime}\right), 116.90$ (C6), 116.68 (C2), 116.59 (C4), $84.03\left(\mathrm{C}_{\mathrm{qFn}}\right)$, 68.70, 68.32, $67.48\left(\mathrm{C}_{\mathrm{Fn}}\right), 34.05\left(\mathrm{CH}_{2 \beta}\right), 29.11\left(\mathrm{CH}_{2 \delta}\right), 26.28$ $\left(\mathrm{CH}_{2 \gamma}\right) ; \mathrm{ESI}-\mathrm{MS} \mathrm{m} / \mathrm{z}=583.2\left[\left(\mathrm{M}+2 \mathrm{MeOH}+2 \mathrm{H}_{2} \mathrm{O}+\mathrm{H}\right)^{+}\right]$; MALDI-HRMS $m / z=482.118$ (calculated for $\mathrm{C}_{28} \mathrm{H}_{26} \mathrm{O}_{4} \mathrm{Fe}=$ 482.118).

\section{Cytotoxic Activity}

Treatment: Stock solutions of RSV and ferrocene-RSV conjugate III were prepared as $20 \mathrm{mM}$ solutions in ethanol (EtOH) and stored at $4^{\circ} \mathrm{C}$. Prior to use in cytotoxicity assay, the stock solutions were further diluted with culture medium to obtain final concentrations $(10-100 \mu \mathrm{M})$.
Cytotoxic effects in Hep G2 and CHO-K1 cells were evaluated after $48 \mathrm{~h}$ of exposition. Samples with ethanol without test compounds were used as controls.

MTT Cytotoxicity Assay: For experimental purposes cells were seeded in multiwell plates $\left(5 \times 10^{4}\right.$ cells $\left./ \mathrm{mL}\right)$, then treated with RSV and III at a range of concentrations $(10-100 \mu \mathrm{M})$ and after $48 \mathrm{~h}$ cell viability was determined by MTT assay. ${ }^{[8]}$ The experiments were performed two times with at least three parallels for each concentration and data were expressed as the means \pm SEM. Cell viability was expressed as percentage of treated cells vs. control cells. The $I_{50}$ values, defined as the concentrations of the tested compound that result in $50 \%$ cell growth inhibition, were derived from the equations of related trend lines.

Statistical Analysis: A two-tailed Student's $t$-test was applied to evaluate the significant differences between control and treated cells. The results are reported as means \pm SEM, $p<0.05$ was considered significant.

\section{RESULTS AND DISCUSSION}

The conjugate III was prepared by esterification ${ }^{[7]}$ of ferrocene butyric acid (1) ${ }^{[6]}$ with C3-OH group of trans-RSV in the presence of DMAP, NEt 3 and $\mathrm{Boc}_{2} \mathrm{O}$ (Scheme 1). Although the reaction conditions were adjusted to provide the simultaneous formation of mono- (III), di- and three esterified conjugates, we were able to isolate and confirm the presence of only one pure compound, i.e. monoester III in yield of $21 \%$. However, TLC-plate indicated the presence of a several yellow-coloured ferrocene-containing compounds that had proved to be difficult to purify to the required level.

The NMR assignments in the present study are in a good agreement with previously published data for $\mathbf{R S V}^{[9,10]}$ and its 3-substituted RSV-glycoside ${ }^{[11]}$ (Table 1).

The ${ }^{1} J(\mathrm{H}, \mathrm{H})$ coupling between two alkene hydrogens $\alpha$ and $\alpha^{\prime}$ of $16.5 \mathrm{~Hz}$ is consistent with the trans orientation of the phenolic rings. MS and NMR data unambiguously confirmed the presence of one single ferrocene moiety, introduced by esterification of $\mathrm{C} 3-\mathrm{OH}$ group of RSV. As it was shown for 3-substituted RSV-glycoside ${ }^{[11]}$, the clearly separated NMR signals of $\mathrm{C} 2$ and $\mathrm{C} 6, \mathrm{C} 3$ and $\mathrm{C} 5$ and $\mathrm{H} 2$ and $\mathrm{H} 6$ in comparison to magnetically equivalent assignments for $\mathrm{H}^{\prime} / 6^{\prime}, \mathrm{H} 3^{\prime} / 5^{\prime}, \mathrm{C2}^{\prime} / 6^{\prime}$ and $\mathrm{C}^{\prime} / 5^{\prime}$ indicate the alteration of their chemical environment due to the esterification of 
Table 1. NMR ( $\delta$ in ppm) spectroscopic data of RSV ${ }^{[9,10]} \mathbf{R S V}$-glycoside ${ }^{[11]}$ and ferrocene-RSV conjugate III $\left(c=1 \times 10^{-3} \mathrm{~mol} \mathrm{dm}^{-3}\right)$

\begin{tabular}{|c|c|c|c|c|c|c|c|}
\hline \multirow{2}{*}{$\begin{array}{c}\mathrm{C} \text { and } \\
\text { attached }{ }^{1} \mathrm{H}\end{array}$} & \multicolumn{3}{|c|}{ Carbon, $\delta / p p m$} & \multicolumn{4}{|c|}{ Proton, $\delta / \mathrm{ppm}$} \\
\hline & $\mathrm{RSV}^{*}$ & RSV-glycoside ${ }^{*}$ & $\mathrm{II}^{* *}$ & RSV $^{*}$ & $\mathrm{RSV}^{* *}$ & RSV-glycoside* & $\| \mathrm{II}^{* *}$ \\
\hline 1 & 139.19 & 139.3 & 139.59 & - & - & - & - \\
\hline 2,6 & 104.23 & $\begin{array}{l}102.7(C 2) \\
107.0(C 6)\end{array}$ & $\begin{array}{l}116.87(C 2) \\
116.54(C 6)\end{array}$ & 6.34 & 6.51 & $\begin{array}{l}6.73(H 2) \\
6.55(H 6)\end{array}$ & $\begin{array}{l}7.19(\mathrm{H} 2) \\
7.11(\mathrm{H} 6)\end{array}$ \\
\hline 4 & 101.67 & 104.7 & 114.20 & 6.07 & 6.21 & 6.33 & 6.90 \\
\hline$\alpha$ & 125.60 & 125.1 & 127.35 & 6.76 & 6.80 & 6.86 & 6.97 \\
\hline$\alpha^{\prime}$ & 128.02 & 128.5 & 129.75 & 6.87 & 6.97 & 7.01 & 7.06 \\
\hline $1^{\prime}$ & 128.07 & 129.9 & 134.49 & - & - & - & - \\
\hline $2^{\prime}, 6^{\prime}$ & 127.75 & 127.9 & 127.73 & 7.35 & 7.35 & 7.39 & 7.47 \\
\hline $3^{\prime}, 5^{\prime}$ & 115.43 & 115.5 & 121.68 & 6.71 & 6.81 & 6.76 & 7.17 \\
\hline $4^{\prime}$ & 157.16 & 157.2 & 151.43 & - & - & - & - \\
\hline 3,5 & 158.28 & $\begin{array}{l}158.2(C 3) \\
158.8(C 5)\end{array}$ & $\begin{array}{l}151.86(C 3) \\
151.85(C 5)\end{array}$ & - & - & - & - \\
\hline
\end{tabular}

C3-OH group. Furthermore, the NOE contacts between free hydroxyl protons on $\mathrm{C}^{\prime}$ and $\mathrm{C} 5$ with $\mathrm{H}^{\prime} / 5^{\prime}$ and $\mathrm{H} 4$, respectively, and $\mathrm{CH}_{2 \beta}$ and $\mathrm{CH}_{2 \gamma}$ with $\mathrm{H} 2$ and $\mathrm{H} 4$ support the proposed structure (Figure 2).

The six protons from alkyl chain were observed as two triplets at $\delta 2.85$ and $2.48 \mathrm{ppm}$ and one multiplet at $1.96 \mathrm{ppm}$. Multiple resonances detected for the same proton during the course of NMR analysis are attributed to the presence of 5:95 cis-trans mixture of RSV.

The RSV and ferrocene-RSV conjugate III were evaluated in vitro as inhibitors of hepatoblastoma (Hep G2) cell proliferation. Also, possible cytotoxicity towards normal ovary cells (CHO-K1) was evaluated. The concentration-dependent analysis of the cytotoxicity was evaluated by the widely used MTT method. The summarized results of cytotoxicity evaluation in Hep $\mathrm{G} 2$ and $\mathrm{CHO}-\mathrm{K} 1$ cell lines with MTT bioassay are presented in Figure 3. $\mathrm{IC}_{50}$ values shown in Table 2 were derived from the equations of related polynomial trend lines for RSV and III, in both cell lines.

Presented data reveal profound effects in biological activity of ferrocene-RSV conjugate III vs. RSV in hepatoblastoma cell line. III in concentrations of 35, 75 and $100 \mu \mathrm{M}$ significantly $(p<0.001-p<0.5)$ decreased Hep G2 cell proliferation (Figure $3 a$ ) and in all tested concentrations inhibitory effect is more pronounced for III compared to the same doses of RSV. This finding is also supported by comparison of $I C_{50}$ values in Hep $\mathrm{G} 2$ cells: $I C_{50}$ value for $I I I$ is $20 \%$ lower than $\mathrm{IC}_{50}$ value for $\mathbf{R S V}^{[4]}$ (Table 2 ). The results in normal CHO-K1 cells (Figure 3b), as opposite to those obtained in Hep G2 carcinoma cells, indicate much lower cytotoxicity of III to normal cells - in fact, there was no statistically significant cytotoxicity observed in normal cells, except for the highest tested concentration $(100 \mu \mathrm{M})$ and $\mathrm{IC}_{50}$ value was out of the applied concentration range.

\section{CONCLUSION}

The previously described ferrocene-RSV derivative IIb, containing two benzene, one ferrocene and one ester group, displayed higher inhibitory activity in SW480 and HepG2 cell lines as compared to RSV, owing to its enhanced lipophilicity. With that in mind, we have synthesized conjugate III comprised of the same elements but with different structural and spatial patterns and equipped with additional trimethylene alkyl chain in order to improve its lipophilicity as a crucial requirement for biological activity. Although the novel conjugate III is found to be less active than IIb, it is more potent in comparison to RSV. Therefore, the herein presented preliminary results hold potential for further studies of ferrocene-RSV conjugates based on multi-method approach in order to obtain more detailed information.

Table 2. IC $C_{50}$ values $(\mu \mathrm{M})$ for $\mathbf{R S V}$ and ferrocene-RSV conjugate III vs. hepatoblastoma (Hep G2) cells and normal ovary cells (CHO-K1) revealed by MTT cytotoxicity assay

\begin{tabular}{|c|c|c|}
\hline \multirow{2}{*}{ Compound } & \multicolumn{2}{|c|}{$\mathrm{IC}_{50}(\mu \mathrm{M})$} \\
\hline & Hep G2 & $\mathrm{CHO}-\mathrm{K} 1$ \\
\hline RSV & 121.5 & 99.0 \\
\hline III & 98.3 & n.d. \\
\hline
\end{tabular}


(a)

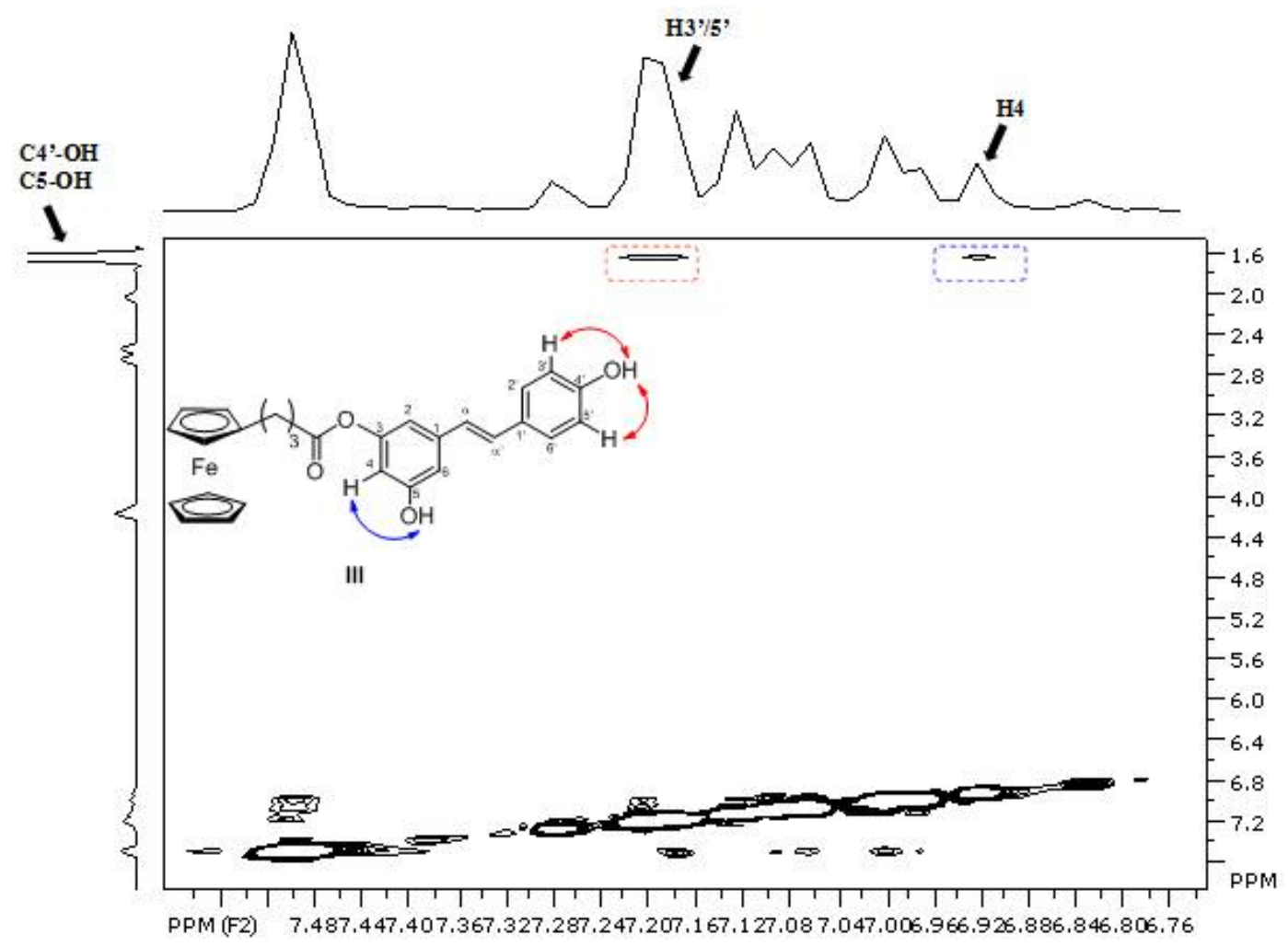

(b)

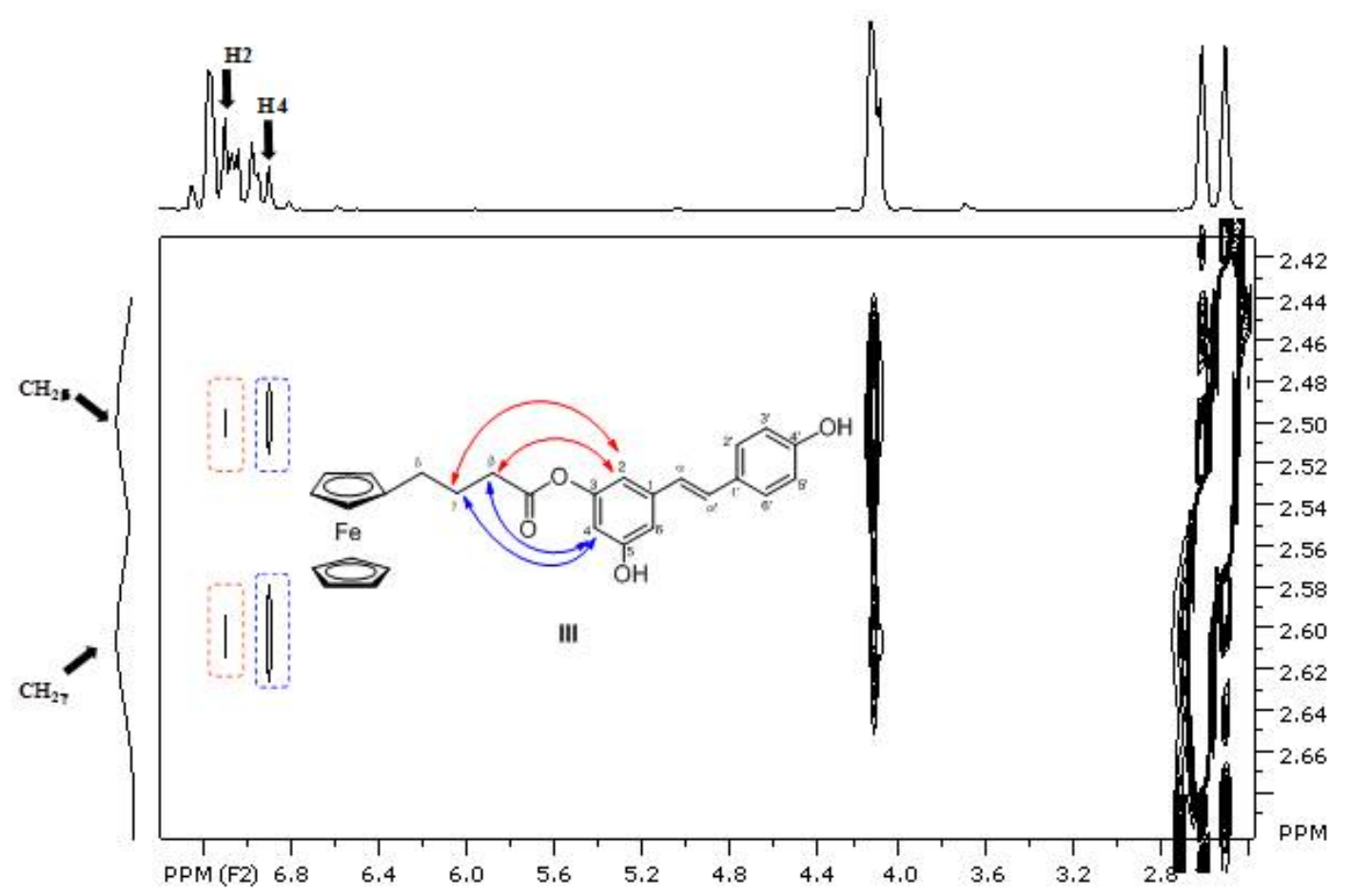

Figure 2. The NOE contacts between (a) free hydroxyl protons on $\mathrm{C} 4^{\prime}$ and $\mathrm{C} 5$ with $\mathrm{H}^{\prime} / 5^{\prime}$ and $\mathrm{H} 4$ and (b) $\mathrm{CH}_{2 \beta}$ and $\mathrm{CH}_{2 \gamma}$ with $\mathrm{H} 2$ and $\mathrm{H} 4$. 

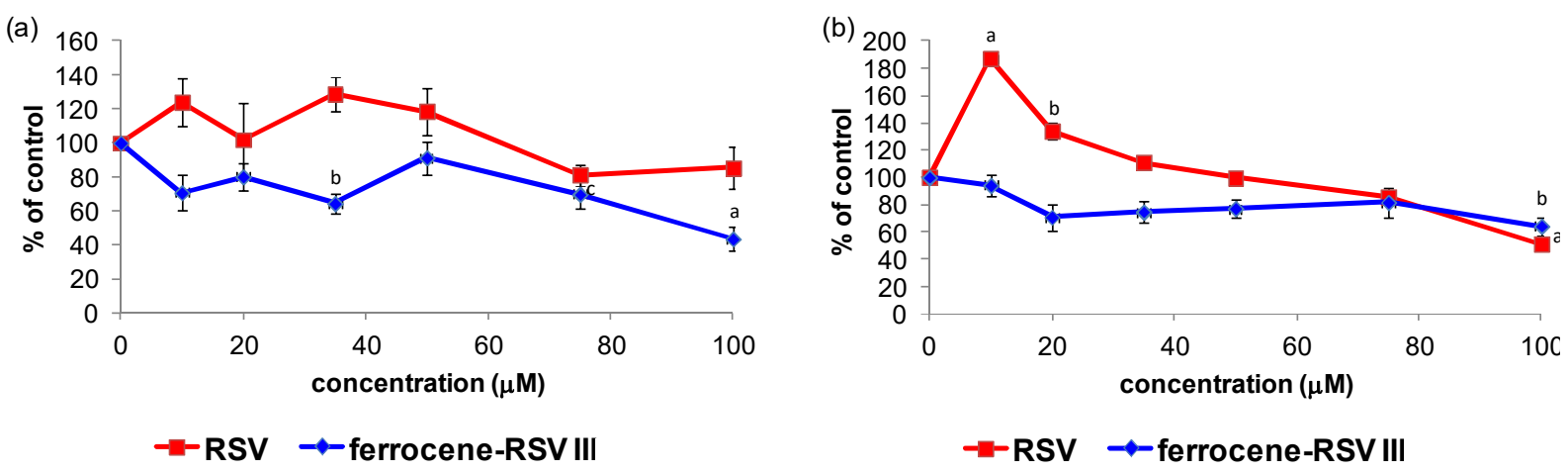

Figure 3. In vitro anti-proliferative effect of RSV and ferrocene-RSV conjugate III against (a) hepatoblastoma (Hep G2) cells and (b) normal ovary cells (CHO-K1), obtained with MTT assay after $48 \mathrm{~h}$ exposure. Data are presented as percentage of control: mean \pm SEM of 2 experiments with at least three measurements within each experiment for each concentration. Statistical significance vs. control: ${ }^{a} p<0.001 ;{ }^{b} p<0.025 ;{ }^{c} p<0.05$.

Acknowledgment. We wish to thank the University of Zagreb for support of this work (Short-term financial support 2015).

Supplementary Information. Supporting information to the paper is enclosed to the electronic version of the article at: http://dx.doi.org/10.5562/cca2992.

\section{REFERENCES}

[1] M. Massimi, A. Tomassini, F. Sciubba, A. P. Sobolev, L. Conti Devirgiliis, A. Miccheli, Biochim. Biophys. Acta 2012, 1820, 1.

[2] J. Das, S. Pany, A. Majhi, Bioorg. Med. Chem. 2011, 19, 5321.

[3] F. Mazué, D. Colin, J. Gobbo, M. Wegner, A. Rescifina, C. Spatafora, D. Fasseur, D. Delmas, P. Meunier, C. Tringali, N. Latruffe, Eur. J. Med. Chem. 2010, 45, 2972.

[4] M. Chalal, D. Delmas, P. Meunier, N. Latruffe, D. Vervandier-Fasseur, Molecules 2014, 19, 7850.
[5] Q. Liu, C. T. Kim, Y. H. Jo, S. B. Kim, B. Y. Hwang, M. K. Lee, Molecules 2015, 20, 16933.

[6] V. Kovač, R. Ribić, V. Petrović Peroković, S. Tomić Pisarović, L. Barišić, Appl. Organometal. Chem. 2016, 30, 524.

[7] I. Held, P. von den Hoff, D. S. Stephenson, H. Zipse, Adv. Synth. Catal. 2008, 350, 1891.

[8] R. I. Freshney, Culture of Animal Cells - a Manual of Basic Technique, Fifth Edition, John Wiley \& Sons, Inc., Hoboken, New Jersey, 2005.

[9] F. Commodari, A. Khiat, S. Ibrahimi, R. Brizius, N. Kalkstein, Magn. Reson. Chem. 2005, 43, 567.

[10] S. Đekić, S. Milosavljević, V. Vajs, S. Jović, A. Petrović, N. Nikić, V. Manojlović, V. Nedović, V. Tešević, J. Serb. Chem. Soc. 2008, 73, 1027.

[11] H. Imai, M. Kitagawa, K. Ishihara, N. Masuoka, K. Shimoda, N. Nakajima, H. Hamada, Biosci. Biotechnol. Biochem. 2012, 76, 1552. 


\section{$\underline{\text { Supplementary Materials }}$}

\section{Materials and methods}

Chemistry: Reaction was carried out under argon atmosphere. The THF used for synthesis was dried and distilled over $\mathrm{CaH}_{2}$ and stored over molecular sieves $(4 \AA)$. The synthesis of ferrocene butyric acid was performed according to literature data ${ }^{[6]}$. Trans-resveratrol (RSV) (Sigma-Aldrich), di-tertbutyldicarbonate (Acros Organics), NEt $_{3}$ (Fischer Chemical) and DMAP (Sigma-Aldrich) were used as received. Product was purified by preparative thin layer chromatography on silica gel (Merck, Kieselgel $60 \mathrm{HF}_{254}$ ). Infrared spectrum was recorded as $\mathrm{CH}_{2} \mathrm{Cl}_{2}$ solution between $\mathrm{NaCl}$ windows by using a Bomem MB 100 mid FTIR spectrometer. (s) = strong, (w) = weak. The ${ }^{1} \mathrm{H}$ NMR spectra measured at $600.133 \mathrm{MHz}$ and ${ }^{13} \mathrm{C}$ NMR spectra measured at $150.917 \mathrm{MHz}$ using Bruker Avance spectrometer, were referenced to the residual solvent peak $\left(\mathrm{CDCl}_{3},{ }^{1} \mathrm{H}: 7.26 \mathrm{ppm},{ }^{13} \mathrm{C}: 77.16 \mathrm{ppm}\right)$. Double resonance experiments (COSY, NOESY, HMBC) were performed in order to assist in signal assignment. (s) = singlet, $($ brs $)=$ broad singlet, $(\mathrm{d})=$ doublet, $(\mathrm{t})=$ triplet, $(\mathrm{m})=$ muliplet, $(\mathrm{pt})=$ pseudotriplet (unresolved doublet of doublets). Mass spectra were measured on a LC-MS system coupled with triple-quadrupole mass spectrometer, operating in a positive ESI mode $\left(\mathrm{H}_{2} \mathrm{O} / \mathrm{MeOH}=\right.$ 80/20). High-resolution mass spectrum was acquired using 4800 MALDI TOF/TOF-MS Analyzer.

Cell culture: Hep G2 (human hepatoblastoma cell line; ATCC $\left(\mathrm{HB}-8065^{\mathrm{TM}}\right.$ ) and CHO-K1 (chinese hamster ovary; ATCC $\left(C C L 61^{\mathrm{TM}}\right.$ ) cell lines were purchased from American Type Culture Collection (ATCC, USA). Hep G2 and CHO-K1 cells were maintained in Dulbecco's Modified Eagle Medium Nutrient Mixture F-12 with 15 mM HEPES buffer and L-glutamine (DMEM/F-12 (1:1); Gibco, Paisley, UK). Heat inactivated Fetal Bovine Serum (Gibco, Paisley, UK) was added to make the complete growth medium for both cell cultures in final concentration of $10 \%$. Cells were routinely cultured in $80-\mathrm{cm}^{2}$ cell flasks (Nunc, Roskilde, Denmark) at $37^{\circ} \mathrm{C}$ and humidified in atmosphere of $5 \% \mathrm{CO}_{2}$ in air. After reaching 70-90\% confluence cells were disaggregated using a trypsin/EDTA $(0.25 \%$ trypsin, $1 \mathrm{mM}$ EDTA.4Na), counted and placed at the necessary density prior to sub-culture or seeding in wells for experimental needs.

Treatment: Hep G2 and CHO-K1 cells in log phase of growth were seeded in 96-well plates $(100 \mu \mathrm{L}$ of cell solution per well) at the initial concentration of $5 \times 10^{4}$ cells $/ \mathrm{mL}$ and allowed $24 \mathrm{~h}$ to attach before treatment with RSV and ferrocene-RSV conjugate. Stock solutions of RSV and ferroceneRSV conjugate III were prepared as $20 \mathrm{mM}$ solutions in ethanol $(\mathrm{EtOH})$ and stored at $4^{\circ} \mathrm{C}$. Prior to use in cytotoxicity assay, the stock solutions were further diluted with culture medium to obtain final concentrations (10-100 $\mu \mathrm{M})$. After $24 \mathrm{~h}$, the media was replaced with fresh one containing different concentrations of RSV or ferrocene-RSV conjugate III. Cytotoxic effects were evaluated after $48 \mathrm{~h}$ of exposition. Samples with ethanol without test compounds were used as controls. Final 
concentration of ethanol did not exceed $0.5 \%$ and had no interference with the biological activities tested. Cytotoxic effects were evaluated after $48 \mathrm{~h}$ of exposition.

MTT Cytotoxicity Assay: The cytotoxicity of RSV and ferrocene-RSV conjugate III was determined by MTT assay. Cells were incubated with tetrazolium salt MTT \{3-[4,5-dimethylthiazol-2-yl]-2,5diphenyl tetrazolium bromide $\}$ for $4 \mathrm{~h}$. The absorbance was measured at $570 \mathrm{~nm}$ on the microplate reader (microplate reader, model LKB 5060-006, LKB Vertriebs GmbH, Vienna, Austria). 